\title{
Experience Value, Satisfaction and Loyalty of International Tourists in Shanghai: A PLS-SEM Analysis
}

\author{
Lilian Consuelo Mustelier Puig ${ }^{1}$, Xu Ming ${ }^{2}$ \\ ${ }^{1} \mathrm{PhD}$ candidate, Glorious Sun School of Business and Management, Donghua University, China \\ ${ }^{2}$ Distinguished professor, Department of Tourism Management, Glorious Sun School of Business and \\ Management, Donghua University, China \\ Correspondence: Lilian Consuelo Mustelier Puig, PhD candidate, Glorious Sun School of Business and \\ Management, Donghua University, China.
}

Received: June 13, 2017

doi:10.5539/ibr.v10n8p114

\author{
Accepted: July 7, 2017 \\ Online Published: July 11, 2017 \\ URL: https://doi.org/10.5539/ibr.v10n8p114
}

\begin{abstract}
The purpose of this paper is to explore loyalty and satisfaction of international tourists visiting Shanghai with tourism services through five experience value dimensions: functional value, price value, emotional value, social value and novelty value. A questionnaire was used to gather data from 166 international tourists visiting Shanghai during September-October, 2016. The measures were taken and adapted from William \& Soutar (2009), and Prebensen \& Rosengren (2016). Data was analyzed using SPSS 24 and SmartPIS 3.2. The results confirm a direct and significant relationship between experience value and its five dimensions. Although all the dimensions of experience value had a significant indirect effect on satisfaction and loyalty, the study showed that international tourists in Shanghai worry more about the emotional, social, and novelty value a service can offer rather than the price or functional value.
\end{abstract}

Keywords: experience value, satisfaction, loyalty, value dimensions, tourism services

\section{Introduction}

Considered to be one of the most popular travel hubs, and the economic and financial center of China, Shanghai has been seen as a city of contrasts, where tradition and modernity converge. This cosmopolitan metropolis is divided by the Huangpu River, and it is this geographic feature which has influenced the formation of the city's center. Indeed, it is the unmistakable photo that all tourists want to have as evidence they have visited Shanghai. It is this riverside image of the city skyline that captures the most instantly recognized profile of this world class city.

According the Shanghai Tourism Bureau ${ }^{1}$, in 2016 the city received 8.543 .700 international tourists, representing an increase of $6.8 \%$ since 2015. Despite the large number of tourists visiting the city, there is a still a lack of understanding by service providers of the needs of international tourists, which results in a failure to meet the market demands by the tourism services. It is true that tourists face barriers, such as language, culture, and customs in every country they visit, nevertheless, when visiting China these barriers can be intensified by a number of factors. For example, many public transportation employees, such as cab drivers, still speak very limited English, so sometimes tourists will not take a taxi because they are afraid of being driven to a different destination. Most prices are quoted in mandarin and when nonverbal communication is employed confusion may arise due to the differences in the finger-counting systems used in China and in the West. Some people recommend to do some basic language study before visiting China, or travel with a calculator while visiting markets where bargaining will be necessary. Many people from other countries are accustomed to tipping when they receive good service, especially in restaurants, however, in China this is not expected. It is common to hear foreigners complaining about the quality of a restaurant, shops overcharging them, crowded routes, forced shopping, or about the toilets. All these barriers influence, in one way or another, the way tourists/consumers

\footnotetext{
${ }^{1}$ Shanghai Tourism Bureau:

http://lyw.sh.gov.cn/lyj_website/HTML/DefaultSite/lyj_xxgk_lytj_2016/2017-03-07/Detail_137492.htm
} 
value their experiences, as well as their feelings of satisfaction and loyalty towards the place visited.

Despite all of the complaints international tourists may have regarding tourism services when visiting the city, when they leave Shanghai will they desire to return? Knowing that bad service can lead to a bad experience and dissatisfaction, and taking into consideration that the overall experience can be viewed as the sum of those interactions that visitors will have with service providers. The following research questions will be used to examine the overall experience of visitors and determine their likelihood of returning to Shanghai:

RQ1: What international tourists really value when visiting Shanghai?

RQ2: With which tourism services (public transportation, attractions, and dining) are visitors most satisfied?

RQ3: Are international tourists willing to recommend the city's tourism services?

\section{Literature Review}

\subsection{Experience Value and Its Dimensions}

Experience has constituted an important notion in both research and practice (Uriely, 2005), and much has been said about it, for example, Pine \& Gilmore (1999) state that experiences are events that engage individuals in a personal way and derive from the individual's prior state of mind and being. In addition, Prebensen et al. (2013) assert that experience value is comprised of the benefits the tourist perceives from a journey to and stay at a destination.

However, when authors refer to experience value, they usually choose to rely on one of the two main concepts of value dimensions, whether the typology of value posited by Holbrook (1999), or the one developed by Sheth et al. (1991) who define five dimensions which have been widely studied within the marketing literature. Sheth et al. outline the powerful tool of using these dimensions (functional, emotional, epistemic, conditional and novelty value) while analyzing the consumer. The authors describe:

- functional value as the perceived utility acquired by an alternative as the result of its ability to perform its functional, utilitarian, or physical purposes (p. 18) that can be measured based on the product attributes or the physical benefits and problems.

- social value as the perceived utility acquired by an alternative as a result of its association with one or more specific social groups (p. 19).

- emotional value is the highest statistically significant dimension in empirical studies related to experience and satisfaction. It is derived from feelings or affective states.

- price value is he utility derived from the product due to the reduction of its perceived short-term and longer term costs (Sweeney \& Soutar, 2001, p. 211).

- novelty value, also called by Sheth et al. as epistemic value, emerges when an alternative provides novelty, arouse curiosity, and/or satisfy knowledge-seeking aspirations (p. 62).

Some authors as Sweeney and Soutar (2001), based on Sheth's work, create a multiple item scale, called PERVAL which includes: emotional, social, and functional value which is comprised of price/ratio and performance quality. Further, Sánchez et al. (2006) developed GLOVAL, a multiple item measure which covers the three underlying categories of perceived value that have remained constant throughout their research: functional value, emotional value and social value (Boksberger \& Melsen, 2011). The authors have linked the experience value dimensions to constructs as satisfaction and loyalty, demonstrating their interrelation.

\subsection{Experience Value on Loyalty}

The literature has proved that customers are loyal to a company as long as it offers them superior value compared to its competitors (Khalifa, 2004). However, only few studies address directly the idea that value, and therefore experience value, has a positive and critical impact in enhancing customer loyalty (e.g. Badgett et al., 2007; Koenig-Lewis and Palmer, 2008; Musa et al., 2013; Klaus and Maklan, 2013). Most of the time loyalty has been measured through satisfaction, and only if a customer highly satisfied will they turn into a loyal customer. However, Reichheld (2003) affirms that loyal customers will recommend a company to their friends, family, and colleagues. This recommendation is one of the best indicators of loyalty because of the customer's risk of reputation. This customer's willingness to recommend to a friend results from how well the customer is treated by frontline employees, which in turn is affected by all the functional areas that contribute to the customer's experience. Hence, we hypothesize that:

H1. Experience Value has a direct effect on Loyalty 


\subsection{Experience Value on Satisfaction}

Prebensen \& Rosengren (2016) defines satisfaction as "the result of the consumer's evaluation of the experience value derived from the experiences at various service providers through the experience process", demonstrating that satisfaction is an evaluation process. This definition has been without doubt, one of the most complete concepts given in the literature. Although most authors agree that satisfaction is a post-purchase and post-consumption evaluation by the consumer (Hunt, 1977; Fornell 1992; Anderson et al., 2008; Luo \& Homburg, 2007), it is well known that experience value has been presented by several authors as one of the predictors of satisfaction (e.g. Bojanic, 1996; Woodruff, 1997; Parasuraman, 1997; Oliver, 1997, 1999; McDougall and Levesque, 2000; Gallarza and Saura, 2006; Ryu et al., 2010; Prebensen et al., 2013; Williams and Soutar, 2009; Prebensen \& Rosengren, 2016; Gallarza et al., 2016). Additionally, experience value dimensions have been linked to satisfaction in positive, direct, and statistically significant ways (e.g. William and Soutar, 2009). Westbrook (1980, 1983) equated satisfaction with emotion and later tested emotion as an antecedent to satisfaction (Westbrook \& Oliver, 1991). Otto and Richie (1996) state that emotions to a great extent affect satisfaction evaluation. Edvardsson et al. (2013) affirm that emotions are critical in evoking customer satisfaction and loyalty. Sheth et al. (1991) posit that utility refers to the satisfaction derived from the physical product or service. William \& Soutar (2009) found that emotional and novelty values affect the level of satisfaction of adventure tourists. Other authors consider novelty value one of the major components of satisfaction (e.g. Crompton, 1979; Bello and Etzel 1985). Functional value has been a key component when referring to consumer satisfaction (e.g. Yang et al., 2014; William and Soutar, 2009). We therefore hypothesize that:

H2. Experience Value has a direct effect on Satisfaction

\subsection{Satisfaction on Loyalty}

Satisfaction and loyalty are two interrelated concepts widely studied in the marketing literature (Fornell, 1992; Fornell et al., 1996; Anderson, 1994; Mittal and Kamakura, 2001; Athanassopoulos et al., 2001; Silvestro and Cross, 2000; Cronin et al., 2000; McDougall and Le vesque, 2000; Gallarza et al., 2015; Gallarza et al., 2016). Authors have related satisfaction and loyalty with concepts such as waiting time (e.g. Bielen and Demoulin, 2007), quality (e.g. Jamal and Naser, 2002), information quality (Goetzinger et al., 2007), image (Ryu, Han, and Kim, 2008; Prayag, 2008), value perception (Sweeney et al., 1996; Parasuraman and Grewal, 2000; Eggert and Ulaga, 2002; Petrick and Backman, 2002; Gallarza and Saura, 2006), and so on. Grønholdt et al. (2000) affirm that customer satisfaction is a key issue for every company wishing to increase customer loyalty and thereby improve business performance. Lemon and Verhoef (2016) assert that one key element of understanding and managing customer experience is the ability to measure and monitor customer reactions to firm offerings. Čater and Čater (2009) define loyalty as a construct that measures the probability that the customer will return and is ready to perform partnering activities such as referrals. Gallarza \& Saura (2006) proved that customer satisfaction is a direct antecedent of customer loyalty and they state that managers might assume that the level of tourist loyalty, both in the repeat behavior and in the positive word of mouth, comes from a higher level of satisfaction. Thus, value has been seen in the literature as the predictor of satisfaction, and satisfaction as the driver of loyalty. Therefore, we can posit the following hypotheses:

H3. Satisfaction has a direct and significant impact on Loyalty

\subsection{Experience Value-Satisfaction-loyalty}

In the last years, several studies headed by Gallarza (Gallarza and Saura, 2006; Gallarza et al., 2015; Gallarza et al., 2016) have researched the value-satisfaction-loyalty chain. The authors state that loyalty considered as a consequence of value and satisfaction is a widespread reality (Cronin et al., 2000; Gallarza et al., 2011; Leroi-Werelds et al., 2014; Parasuraman and Grewal, 2000; cited in Gallarza et al., 2016). In 2015, Gallarza et al. found that satisfaction is the behavioral consequence of perceived value, with loyalty being the final outcome ( $\mathrm{p}$. 147). One year later, Gallarza et al. (2016) fully confirmed value-satisfaction-loyalty as the basis of the consumer behavior, with strong linkages, especially within the first link of the value-satisfaction-loyalty chain. Other works (e.g. Chen and Tsai, 2007; McDougall and Levesque, 2000) also consider the mediation role of satisfaction between experience value and loyalty. So we hypothesize that:

H4. Satisfaction mediates the relationship between Experience Value and Loyalty

\section{Methodology}

In our study we will use a second-order reflective-formative hierarchical model, type II (for more see Becker, Klein and Wetzels, 2012) with a two-stage approach. We follow the studies of Hair et al (2017); Rahman et al 
(2017); Sarstedt et al (2014); Henseler, Ringle and Sarstedt (2014); Becker, Klein and Wetzels (2012), which give clear steps about how to analyze reflective and formative constructs in Smart PLS-SEM. Figure 1 shows one exogenous latent variable, which is also seen as the second-order latent variable, integrated by five first-order reflective variables (Functional Value, Price Value, Emotional Value, Social Value, Novelty Value) which form the formative construct, with their respective reflective indicators. This exogenous latent variable called Experience Value functions as the predictor of Satisfaction, which at the same time works as an endogenous latent variable that has a dual relationship with both independent and dependent (Hair et al., 2017). In our model, Satisfaction functions as the predictor of Loyalty, which is another endogenous variable.

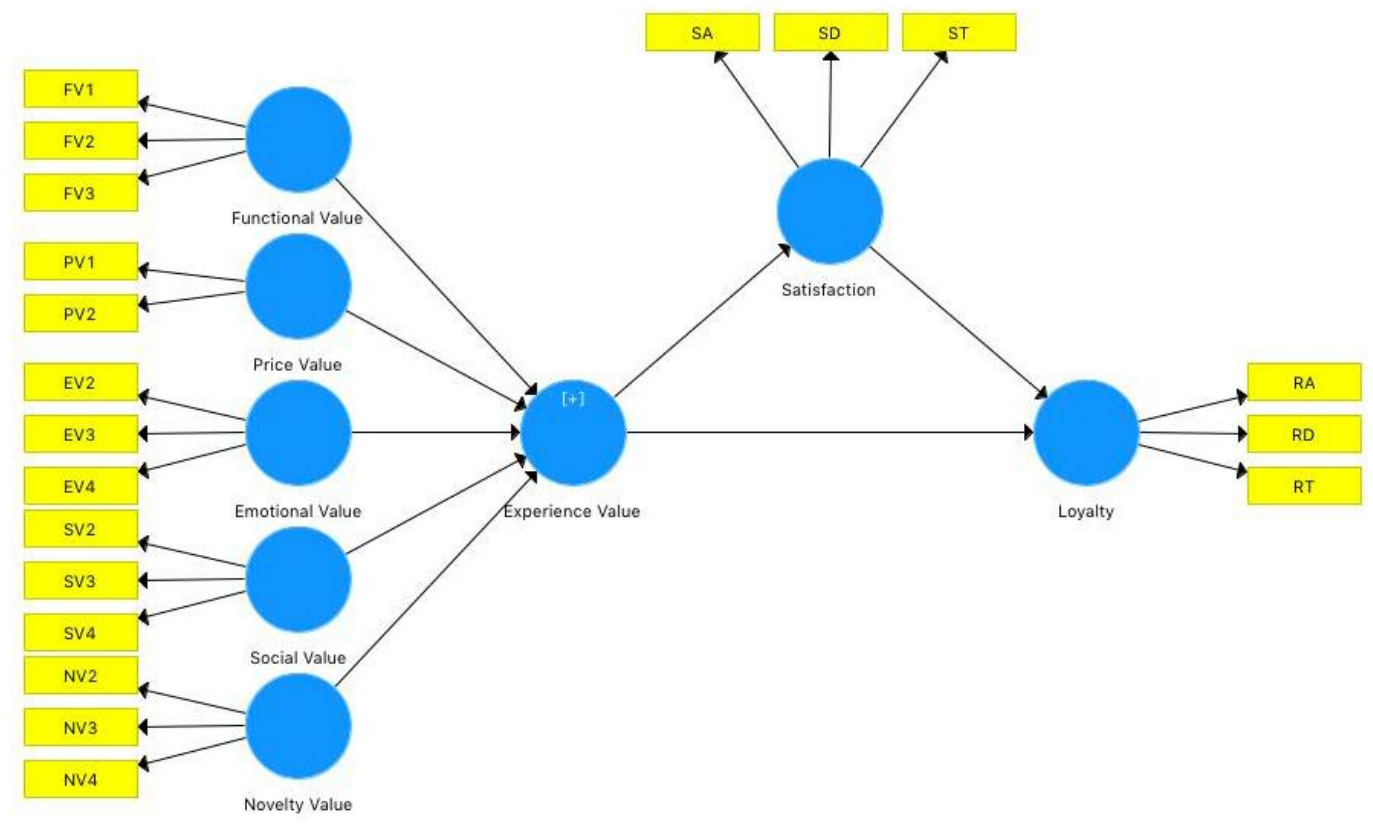

Figure 1. Proposed Model

\subsection{Sampling and Data Collection}

The target population of the study consists of international tourists visiting Shanghai, from September 25th to October 18th, 2016. Specifically, 300 questionnaires were distributed physically and via WeChat of which only returned 180 were returned and from those 14 of them were excluded because they were filled by tourist from Hong Kong and Macao. The questionnaire contains four parts: the first part for demographic variables (5 items); the second part comprise the experience value dimensions ( 5 items) based on a seven-point Likert Scale, being 1 "strongly disagree" and 7 "strongly agree" the respondents needed to evaluate their experiences while interacting with tourism services in Shanghai, following different the value dimensions (table 1), this part was adapted from Williams and Soutar's (2009) scale of experience value and Prebensen and Rosengren (2016) who applied the Williams and Soutar's scale. At the same time, these authors took the dimensions of value from Sweeney and Soutar's (2001) PERVAL scale, adding the novelty value dimension due to its importance in the tourism context as the author state; third, tourist satisfaction was evaluated using three items of Prebensen and Rosengren's (2016) adapted to tourism services in Shanghai, based on a seven-point Likert Scale the tourist were asked: How satisfied or unsatisfied are you with the following services? $(1=$ completely unsatisfied, $7=$ completely satisfied), only three main tourism services were related in the study (public transportation, attractions and dining). The last question was related with service loyalty, measured with one question: How likely would you be to recommend the public transportation, attractions and dining to your friends? using a seven-point Likert Scale were 1 was "not at all likely" and 7 was "very likely". To analyze the data, first SPSS 24 was used in order to screen the data and check the model validity. Secondly, we proceeded to analyze the data with SmartPLS 3.2 
Table 1. Constructs used to measure Experience Value

\begin{tabular}{lll}
\hline \multicolumn{1}{c}{ Constructs } & Indicators & \multicolumn{1}{c}{ Questions } \\
\hline Functional Value & FV1 & Shanghai tourism services provide a consistent level of quality \\
& FV2 & Shanghai tourism services are well-planned \\
& FV3 & Shanghai tourism services maintains an acceptable standard of quality \\
Price Value & PV1 & Shanghai tourism services are affordably priced \\
& EV2 & Shanghai tourism services worth what I paid \\
Emotional Value & EV3 & Shanghai tourism services make me feel happy \\
& EV4 & Shanghai tourism services make me feel excited \\
Social Value & SV2 & Using Shanghai tourism services make me feel acceptable to others \\
& SV3 & Using Shanghai tourism services improve my social status \\
& SV4 & Using Shanghai tourism services make me feel accepted by my peers \\
Novelty Value & NV2 & By using Shanghai tourism services I feel an authentic and genuine experience \\
& NV3 & Using Shanghai tourism services make me feel adventurous \\
& NV4 & Shanghai tourism services experience is unique \\
\hline
\end{tabular}

Source: Based on Williams and Soutar (2009); Prebensen and Rosengren (2016)

\section{Data Anal ysis and Findings}

\subsection{Data Screening and Test for Common Method Bias}

Firstly, we checked how accurately our data was by exploring its missing values and later proceed to test it for common method bias. Bagozzi \& Yi (1991) posit that common method bias (CMB) is the variance that is attributed to the measurement method rather than to the construct of interest, which an important element while testing a model. Therefore, in order to detect if our model suffered from CMB, we performed Harman's one-factor test (Podsakoff et al., 2003), followed by the calculation of Pearson correlation coefficient, known as one of the most popular statistic for measuring the association between the two variables (Stigler, 1989). The Harman's one-factor test gave us a result of 20 components, with a variance of $36.328 \%$, lower than the threshold value of 50\%, meaning that our data is unlike being affect by CMB. The Pearson correlation coefficients were all above 0.80 (see Appendix 1). Moreover, we can affirm that our data is unlikely to be affected by CMB and proceed to its analysis using PLS-SEM.

Table 2. Demographics

\begin{tabular}{|c|c|c|c|}
\hline Profile & Groups & Frequency & Percentage \\
\hline \multirow{2}{*}{ Gender } & Female & 84 & 50.6 \\
\hline & Male & 82 & 49.4 \\
\hline \multirow[t]{5}{*}{ Age } & Below 18 & 2 & 1.2 \\
\hline & $18-25$ & 72 & 43.4 \\
\hline & $26-30$ & 33 & 19.9 \\
\hline & $31-40$ & 51 & 30.7 \\
\hline & Above 41 & 8 & 4.8 \\
\hline \multirow[t]{7}{*}{ Continent } & the Americas and the Caribbean & 64 & 38.5 \\
\hline & Asia & 37 & 21.6 \\
\hline & Europe & 30 & 17.4 \\
\hline & Africa & 23 & 13.2 \\
\hline & Middle East & 5 & 3 \\
\hline & Australia and Oceania & 2 & 1.2 \\
\hline & Non - respondents & 5 & 3.0 \\
\hline \multirow[t]{8}{*}{ Education } & High school graduate & 19 & 11.4 \\
\hline & College & 24 & 14.5 \\
\hline & Technical/vocational training & 1 & 0.6 \\
\hline & Associate degree & 2 & 1.2 \\
\hline & Bachelor degree & 74 & 44.6 \\
\hline & Master degree & 34 & 20.5 \\
\hline & Doctorate degree & 11 & 6.6 \\
\hline & Non - respondents & 1 & 0.6 \\
\hline \multirow[t]{4}{*}{ Occupation } & Student & 84 & 50.6 \\
\hline & Office/corporate worker & 29 & 17.5 \\
\hline & Teacher & 28 & 16.9 \\
\hline & Other & 25 & 15 \\
\hline
\end{tabular}

\subsection{Sample Characteristic}

Table 2 summarizes the demographics of the respondents, the percentages of male (50.6\%) and female (49.4\%) respondents was very closed. The sample shows that $50.6 \%$ of the international tourists surveyed were students, 
$17.5 \%$ were corporate workers, $16.9 \%$ were teachers, the rest of the other $15 \%$ were among freelancers, service personnel, government workers, human resources employees and others. The highest percentage of occupational level was bachelor degree (44.6\%) and master (20.5\%). The respondents were from 49 different countries. The Americas and the Caribbean had the highest percentage (38.5\%) of respondent. In terms of occupations, half of the sample were students.

\section{Measurement Model}

Becker, Klein and Wetzels (2012) refer to three different approaches while analyzing data through PLS-SEM, the repeated indicator approach, the hybrid approach, and the two-stage approach. The authors explain that the two-stage approach possibilities the estimation of the construct scores of the first-order constructs in a first-stage model without the second-order construct present, and subsequently uses these first-stage construct scores as indicators for the higher- order latent variable in a separate second-stage analysis (p.365). The analysis was made in three steps: (1) the reflective constructs, for which we report the convergent validity, discriminant validity, composite reliability, and collinearity. (2) the results of the formative construct can be seen through the construct validity, the collinearity, and and indicator weights are reported. Finally, the structural model was analyzed.

\subsection{Evaluation of the Reflective Construct}

\subsubsection{Convergent Validity}

In order to see how well the variables correlate, we calculated the conversion validity, namely, the degree to which multiple items to measure the same concept are in agreement' (Amin et al., 2016). For this, the researcher should look at: (1) the loadings higher than $0.70,(2)$ the composite reliability (CR) values should be higher than 0.60 and lower than 0.95 , and (3) the average variance extracted (AVE) should be greater than 0.70 . Hair et al $(2014,2017)$ recommend to report the internal consistency of the measurement model computing Cronbach's alpha and the composite reliability, besides the convergent validity and the discriminant validity. Exhibit 1 summarizes the evaluation of the reflective indicators. For convergent validity all the values are above 1.96 , the $p$ values are significant at 0.001 . All the AVE values are ranged between 0.683 (novelty value) and 0.818 (price value). The composite reliability values fluctuate between 0.866 (novelty value) and 0.900 (emotional value) showing a great consistency with each other. Cronbach's alpha values are ranged between 0.769 and 0.833 , and finally the loading values are above the starting point of 0.7 . Moreover, we can affirm that the constructs are well correlated and the convergent validity is proved.

Exhibit 1. Convergent Validity for the reflective constructs

\begin{tabular}{|c|c|c|c|c|c|c|c|}
\hline Latent Variables & Indicators & Loading & CA & CR & AVE & $t$-statistics & $p$-values \\
\hline \multirow[t]{3}{*}{ Emotional Value } & EV2 & 0.915 & 0.833 & 0.900 & 0.750 & 57.231 & 0.000 \\
\hline & EV3 & 0.869 & & & & 36.586 & 0.000 \\
\hline & EV4 & 0.811 & & & & 21.776 & 0.000 \\
\hline \multirow[t]{3}{*}{ Functional Value } & FV1 & 0.874 & 0.821 & 0.893 & 0.736 & 30.155 & 0.000 \\
\hline & FV2 & 0.859 & & & & 36.856 & 0.000 \\
\hline & FV3 & 0.841 & & & & 25.215 & 0.000 \\
\hline \multirow[t]{3}{*}{ Novelty Value } & NV2 & 0.837 & 0.769 & 0.866 & 0.683 & 17.112 & 0.000 \\
\hline & NV3 & 0.866 & & & & 25.384 & 0.000 \\
\hline & NV4 & 0.775 & & & & 15.795 & 0.000 \\
\hline \multirow[t]{2}{*}{ Price Value } & PV1 & 0.847 & 0.795 & 0.899 & 0.818 & 5.949 & 0.000 \\
\hline & PV2 & 0.958 & & & & 11.255 & 0.000 \\
\hline \multirow[t]{3}{*}{ Social Value } & SV2 & 0.858 & 0.832 & 0.899 & 0.748 & 23.875 & 0.000 \\
\hline & SV3 & 0.866 & & & & 26.073 & 0.000 \\
\hline & SV4 & 0.871 & & & & 22.452 & 0.000 \\
\hline
\end{tabular}

Note. $\mathrm{CA}=$ Cronbach Alpha; $\mathrm{CR}=$ Composite Reliability; $\mathrm{AVE}=$ average variance extracted

\subsubsection{Discriminant Validity}

To assess the discriminant validity, we first use the Fornell-Larcker criterion (Exhibit 2) which help us to identify if the square root of the AVE is greater than any of the inter-construct correlations. Secondly, we examine the cross loadings (Exhibit 3), where each indicator should load highest on the construct it is associated with (Hair et al., 2017). For both Fornell-Larcker and cross loadings the discriminant validity in our study was established. However, these criterions are insufficiently sensitive to detect problems while assessing discriminant validity (Henseler, Ringle and Sarstedt, 2015), we therefore examined the Heterotrait-monotrait ratio (HTMT) in order to achieve high specificity and sensitivity rates across all simulations. Exhibit 4 shows value in between 0.10 in respect of HTMT (SV, PV) and 0.70 in respect of (SV, EV) being significantly different from 0.90 (Exhibit 4) (for more see: Henseler, Ringle and Sarstedt, 2015). Hence, discriminant validity has been established. 
Exhibit 2. Fornell-Larcker criterion

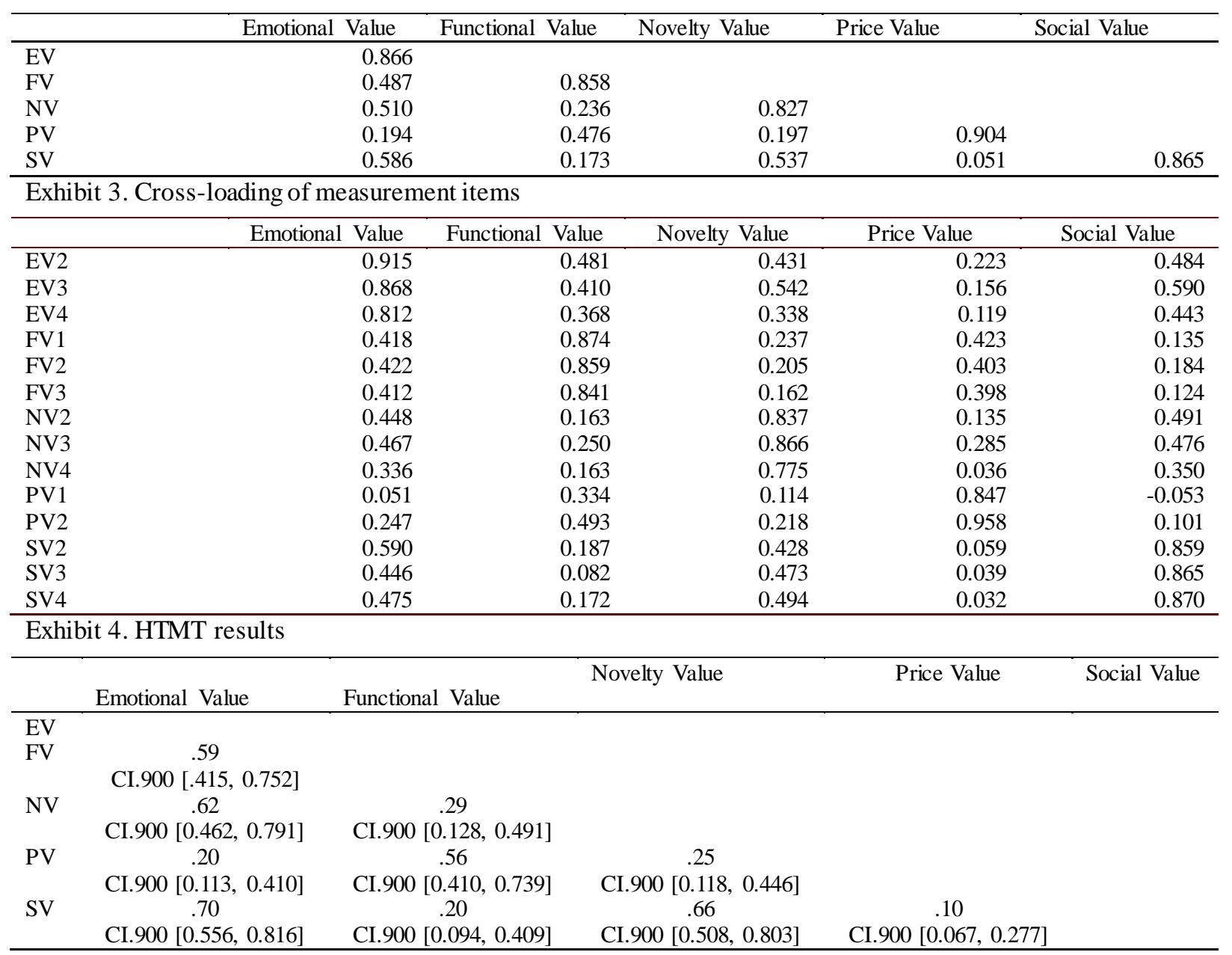

5.2 Evaluation of the Formative Indicators

In order to analyze the formative indicators, we examine: (1) the convergent validity by correlating the formatively measured construct with a reflective measure of the same construct, measured by the indicator weights, and (2) collinearity among the indicators by the outer VIF values.

Exhibit 6. Indicator Weights

\begin{tabular}{lrrrrr}
\hline \multicolumn{1}{c}{ Path } & $\begin{array}{c}\text { Outer Weights } \\
(w)\end{array}$ & $t$-statistics & $p$ values & $\begin{array}{c}95 \% \text { BCa } \\
\text { Confidence Interval }\end{array}$ & $\begin{array}{c}\text { Significance } \\
(\mathrm{p}<0.05)\end{array}$ \\
\hline EV2 <- Experience Value & 0.160 & 11.630 & 0.000 & {$[0.139,0.197]$} & Yes \\
EV3 <- Experience Value & 0.155 & 10.977 & 0.000 & {$[0.133,0.191]$} & Yes \\
EV4 <- Experience Value & 0.144 & 9.887 & 0.000 & {$[0.121,0.178]$} & Yes \\
FV1 <- Experience Value & 0.119 & 6.464 & 0.000 & {$[0.081,0.153]$} & Yes \\
FV2 <- Experience Value & 0.124 & 8.635 & 0.000 & {$[0.096,0.150]$} & Yes \\
FV3 <- Experience Value & 0.118 & 6.989 & 0.000 & {$[0.086,0.153]$} & Yes \\
NV2 <- Experience Value & 0.101 & 4.813 & 0.000 & {$[0.057,0.140]$} & Yes \\
NV3 <- Experience Value & 0.116 & 9.169 & 0.000 & {$[0.094,0.143]$} & Yes \\
NV4 <- Experience Value & 0.086 & 5.040 & 0.000 & {$[0.042,0.113]$} & Yes \\
PV1 <- Experience Value & 0.048 & 2.292 & 0.022 & {$[0.000,0.079]$} & No \\
PV2<- Experience Value & 0.096 & 5.776 & 0.000 & {$[0.058,0.122]$} & Yes \\
SV2 <- Experience Value & 0.125 & 8.719 & 0.000 & {$[0.103,0.159]$} & Yes \\
SV3 <- Experience Value & 0.101 & 6.793 & 0.000 & {$[0.072,0.128]$} & Yes \\
SV4 <- Experience Value & 0.108 & 5.343 & 0.000 & {$[0.060,0.142]$} & Yes \\
SA <- Satisfaction & 0.499 & 10.558 & 0.000 & {$[0.422,0.611]$} & Yes \\
SD <- Satisfaction & 0.461 & 10.007 & 0.000 & {$[0.383,0.565]$} & Yes \\
ST <- Satisfaction & 0.408 & 8.500 & 0.000 & {$[0.298,0.492]$} & Yes \\
RA <- Loyalty & 0.457 & 11.589 & 0.000 & {$[0.394,0.552]$} & Yes \\
RD <- Loyalty & 0.442 & 12.099 & 0.000 & {$[0.380,0.536]$} & Yes \\
RT <- Loyalty & 0.413 & 8.673 & 0.000 & {$[0.314,0.498]$} & Yes \\
\hline
\end{tabular}




\subsubsection{Construct Validity for the Formative Measures}

The construct validity can be measured by the indicator weights, which is the result of a multiple regression (Hair et al., 2010) with the latent variable scores as the dependent variable and the formative indicators as the independent variables (Hair et al., 2017). The authors also recommend to report the confidence intervals because they provide additional information on the stability of a coefficient estimate (p. 155). They claim that if the confidence interval of a coefficient is wider, then its stability is lower. Exhibit 6 presents all the outer weight values of the formative indicators, which are all different from zero, at a 95\% of confidence intervals and significant at $5 \%$ probability of error level, explaining the relation to the construct.

\subsubsection{Collinearity}

Collinearity is no more than the high correlation between the formative indicators. While examining formative measures, it is important to assess the variance inflation factor (VIF), defined as the reciprocal of the tolerance (Hair et al., 2014, 2017), thus, VIFs greater than 5 suggest the existence of collinearity in the context of variance-based SEM. Exhibit 7 shows that all the outer VIF values are below the threshold value of 5 .

Exhibit 7. Outer VIF values

\begin{tabular}{lrlr}
\hline & VIF & VIF \\
\hline EV2 & 2.613 & PV2 & 2.250 \\
EV3 & 2.040 & SV2 & 2.160 \\
EV4 & 1.747 & SV3 & 2.046 \\
FV1 & 1.966 & SV4 & 2.006 \\
FV2 & 1.823 & RA & 1.334 \\
FV3 & 1.762 & RD & 1.329 \\
NV2 & 1.980 & RT & 1.163 \\
NV3 & 2.071 & SA & 1.148 \\
NV4 & 1.481 & SD & 1.180 \\
PV1 & 2.076 & ST & 1.155 \\
\hline
\end{tabular}

Note. $\mathrm{VIF}=$ variance inflation factor

\subsection{Structural Model}

After analyzing the second-order construct through a repeated indicator approach, we then started to analyze the structural model through the following steps: (1) structural model for collinearity issues, (3) the level of $R^{2}(4)$ the $f^{2}$ effect size. (5) the predictive relevance $Q^{2},(6)$ significance and relevance of the structural model relationships, and (7) total effects.

\subsubsection{Collinearity of the structural model}

In order to assess the collinearity of the structural model we check the inner VIF values. Exhibit 8 shows that all the values are clearly below the threshold of 5 . Therefore, collinearity among the predictor constructs is not a critical issue in the structural model (Hair et al., 2017, p. 211)

Exhibit 8. Inner VIF values

\begin{tabular}{lcrr}
\hline & Experience Value & Loyalty & Satisfaction \\
\hline Experience Value & & 1.558 & 1.000 \\
Emotional Value & 2.114 & & \\
Functional Value & 1.667 & & \\
Loyalty & 1.568 & & \\
Novelty Value & 1.326 & & \\
Price Value & 1.779 & 1.558 & \\
Social Value & & & \\
Satisfaction & &
\end{tabular}

To assess the significance and relevance of the structural model relationships it is important to analyze the coefficient of determination $\left(R^{2}\right) . R^{2}$ values of $0.75,0.50$ and 0.25 may be considered substantial, moderate and weak, respectively (Sarstedt et al., 2014; Hair et al., 2011; Henseler et al., 2009). In our structural model, the coefficient of determination is satisfactory. Experience Value shows the highest level of prediction $\left(R^{2}=1.000\right)$, whilst the prediction of Satisfaction $\left(R^{2}=0.358\right)$, and Loyalty $\left(R^{2}=0.560\right)$ have a moderate $R^{2}$.

\subsubsection{The $f^{2}$ Effect Size}

The $f^{2}$ effect size values of small (0.02), medium (0.15), and large (0.35) are the one researcher look at while assessing $f^{2}$. Effect size values of less than 0.02 indicate that there is no effect (Hair et al. 2017). See that, 
Experience Value has large effect size on Satisfaction $\left(f^{2}=0.558\right)$, and Satisfaction on Loyalty with the largest effect size $\left(f^{2}=0.628\right)$, followed by Experience Value on Loyalty $\left(f^{2}=0.028\right)$.

\subsubsection{Predictive Relevance $\mathrm{Q}^{2}$}

Hair et al. (2017) state that the predictive relevance $\left(Q^{2}\right)$ or blindfolding values larger than 0 suggest that the model has predictive relevance for a certain endogenous construct. In contrast, values of 0 and below indicates a lack of predictive relevance (p. 207). All the values of our construct were above zero (Experience Value $=0.337$, Loyalty $=0.300$, and Satisfaction $=0.172$ ), providing support for the model's predictive relevance (Sarstedt et al., 2014).

\subsubsection{Significance and Relevance of the Structural Model Relationships}

Exhibit 9 reveals the strong importance of emotional value $(\beta=0.402)$, and functional value $(\beta=0.310)$ on Experience Value, followed by social value $(\beta=0.288)$, and novelty value $(\beta=0.250)$; however, price value shows a weak effect $(\beta=0.133)$ on Experience Value despite being statistically significant. Besides, Experience Value reveals a strong significant effect on Satisfaction $(\beta=0.599, \mathrm{t}=10.420, \mathrm{p}<0.05)$ proving our second hypothesis $(\mathrm{H} 2)$, and Satisfaction on Loyalty $(\beta=0.656, \mathrm{t}=8.703, \mathrm{p}<0.05)$ demonstrating the third hypothesis (H3). In addition, Exhibit 9 shows that our first hypothesis (H1) is rejected.

Exhibit 9. Path Coefficients of the Structural Model

\begin{tabular}{|c|c|c|c|c|c|}
\hline Path & $\begin{array}{c}\text { Path } \\
\text { Coefficients } \\
(\beta)\end{array}$ & $t$-Statistics & $\begin{array}{c}p \\
\text { Values }\end{array}$ & $\begin{array}{c}95 \% \\
\text { Confidence } \\
\text { Intervals }\end{array}$ & $\begin{array}{c}\text { Significance } \\
(\mathrm{p}<0.05)\end{array}$ \\
\hline Emotional Value $\longrightarrow$ Experience Value & 0.402 & 12.092 & 0.000 & {$[0.337,0.471]$} & Yes \\
\hline Functional Value $\rightarrow$ Experience Value & 0.310 & 8.076 & 0.000 & {$[0.231,0.377]$} & Yes \\
\hline Novelty Value $\longrightarrow$ Experience Value & 0.250 & 8.196 & 0.000 & {$[0.188,0.313]$} & Yes \\
\hline Price Value $\longrightarrow$ Experience Value & 0.133 & 4.278 & 0.000 & {$[0.058,0.181]$} & Yes \\
\hline Social Value $\longrightarrow$ Experience Value & 0.288 & 8.095 & 0.000 & {$[0.213,0.361]$} & Yes \\
\hline Experience Value $\longrightarrow$ Satisfaction & 0.599 & 10.420 & 0.000 & {$[0.482,0.701]$} & Yes \\
\hline Satisfaction $\longrightarrow$ Loyalty & 0.656 & 8.703 & 0.000 & {$[0.510,0.799]$} & Yes \\
\hline Experience Value $\rightarrow$ Loyalty & 0.140 & 1.737 & 0.083 & {$[-0.008,0.298]$} & No \\
\hline \multicolumn{6}{|c|}{ Exhibit 10. Total Effects of the Structural Model } \\
\hline Path & Total Effect & $t$-Statistics & $p$ Values & $\begin{array}{c}95 \% \\
\text { Confidence } \\
\text { Intervals } \\
\end{array}$ & $\begin{array}{c}\text { Significance } \\
(\mathrm{p}<0.05)\end{array}$ \\
\hline Emotional Value $\longrightarrow$ Experience Value & 0.402 & 12.092 & 0.000 & {$[0.337,0.471]$} & Yes \\
\hline Emotional Value $\longrightarrow$ Loyalty & 0.214 & 7.136 & 0.000 & {$[0.152,0.280]$} & Yes \\
\hline Emotional Value $\longrightarrow$ Satisfaction & 0.240 & 8.303 & 0.000 & {$[0.187,0.299]$} & Yes \\
\hline Functional Value $\longrightarrow$ Experience Value & 0.310 & 8.076 & 0.000 & {$[0.231,0.377]$} & Yes \\
\hline Functional Value $\longrightarrow$ Loyalty & 0.165 & 5.634 & 0.000 & {$[0.110,0.222]$} & Yes \\
\hline Functional Value $\longrightarrow$ Satisfaction & 0.185 & 5.954 & 0.000 & {$[0.126,0.244]$} & Yes \\
\hline Novelty Value $\longrightarrow$ Experience Value & 0.250 & 8.196 & 0.000 & {$[0.188,0.313]$} & Yes \\
\hline Novelty Value $\longrightarrow$ Loyalty & 0.133 & 6.322 & 0.000 & {$[0.097,0.175]$} & Yes \\
\hline Novelty Value $\longrightarrow$ Satisfaction & 0.149 & 7.660 & 0.000 & {$[0.115,0.191]$} & Yes \\
\hline Price Value $\longrightarrow$ Experience Value & 0.133 & 4.278 & 0.000 & {$[0.058,0.181]$} & Yes \\
\hline Price Value $\longrightarrow$ Loyalty & 0.071 & 3.740 & 0.000 & {$[0.031,0.103]$} & Yes \\
\hline Price Value $\longrightarrow$ Satisfaction & 0.079 & 3.803 & 0.000 & {$[0.033,0.117]$} & Yes \\
\hline Social Value $\longrightarrow$ Experience Value & 0.288 & 8.095 & 0.000 & {$[0.213,0.361]$} & Yes \\
\hline Social Value $\longrightarrow$ Loyalty & 0.153 & 6.516 & 0.000 & {$[0.109,0.201]$} & Yes \\
\hline Social Value $\longrightarrow$ Satisfaction & 0.172 & 7.480 & 0.000 & {$[0.123,0.213]$} & Yes \\
\hline Experience Value $\longrightarrow$ Satisfaction & 0.599 & 10.420 & 0.000 & {$[0.482,0.701]$} & Yes \\
\hline Experience Value $\longrightarrow$ Loyalty & 0.533 & 8.479 & 0.000 & {$[0.411,0.660]$} & Yes \\
\hline Satisfaction $\longrightarrow$ Loyalty & 0.656 & 8.703 & 0.000 & {$[0.510,0.799]$} & Yes \\
\hline
\end{tabular}

5.3.6 Total Effects

In order to check the indirect effect of the exogenous variable on the endogenous variable via the mediating construct which is Satisfaction, we followed the steps given by Hair et al. (2017) and Sarstedt et al. (2014). We then bootstrapped and saw the total effects. Exhibit 10 summarizes all the total effect of the model. Within the first-order construct, we can observe how emotional value has the strongest significant effect on satisfaction $(t=$ $8.303, p=0.000)$, and loyalty $(t=7.136, p=0.000)$, followed by social value $(t=7.480, p=0.000 ; t=6.516, p$ $=0.000)$, novelty value $(t=7.660, p=0.000 ; t=6.322, p=0.000)$, functional value $(t=5.954, p=0.000 ; t=$ 5.634, $p=0.000)$, and price value $(t=3.803, p=0.000 ; t=3.740 p=0.000)$. Therefore, service providers should focus more on the emotional aspects of the service, as well as the social value, and no velty in order to attract 
more international tourists. Exhibit 10 indicates that all the confidence intervals are above zero, therefore all the paths are significant. However, despite the total effect of experience value on loyalty shows significance, experience value does not have a direct effect on loyalty as the path coefficients of the structural model proved that $t$ statistics is below 1.96 .

\subsection{Mediation Analysis}

In order to test if Satisfaction mediates or not the relationship between Experience Value and Loyalty, all the calculations media above need to be done. For testing mediation through PLS we bootstrap our model and analyze the direct and indirect effects, together with the the confidence intervals of every path. Following Hair et al. (2017), exhibit 11 shows that the indirect effect (0.393) of Experience Value $\rightarrow$ Loyalty is significance at confidence intervals of $95 \%$, followed by the t-statistics value of 5.966, and $p$ value of 0.000 . In contrast, the direct effect (0.140) of Experience Value $\longrightarrow$ Loyalty is relatively weak (0.140) comparing to the indirect effect, and statistically nonsignificant $(\mathrm{t}=1.737 ; \mathrm{p}=0.083)$. Therefore, we conclude that Satisfaction fully mediates the relationship of Experience Value $\longrightarrow$ Loyalty, accepting our fourth hypothesis (H4).

Exhibit 11. Mediation Analysis

\begin{tabular}{|c|c|c|c|c|c|c|c|c|}
\hline Path & DF & $\begin{array}{l}95 \% \\
\text { CI of } \\
\text { Direct } \\
\text { Effect }\end{array}$ & $t$-Statistics & $\begin{array}{c}\text { Significance } \\
(\mathrm{p}<0.05)\end{array}$ & $\mathrm{IF}$ & $\begin{array}{l}95 \% \text { CI of } \\
\text { Indirect } \\
\text { Effect }\end{array}$ & $t$-Statistics & $\begin{array}{l}\text { Significance } \\
(\mathrm{p}<0.05)\end{array}$ \\
\hline $\begin{array}{l}\text { Experience } \\
\text { Value } \quad \rightarrow \\
\text { Loyalty }\end{array}$ & 0.140 & $\begin{array}{r}{[-0.008,} \\
0.298]\end{array}$ & 1.737 & 0.083 & 0.393 & $\begin{array}{c}{[0.271,} \\
0.514]\end{array}$ & 5.966 & 0.000 \\
\hline
\end{tabular}

Note. $\mathrm{DF}=$ Direct Effect; $\mathrm{Cl}=$ Confidence Interval; $\mathrm{IE}=$ Indirect Effect

\section{Discussion}

The study has explored loyalty and satisfaction of international tourists visiting Shanghai with tourism services through five experience value dimensions: functional value, price value, emotional value, social value and novelty value, taking into consideration three of the main tourism services in the city (transportation, dining, and attractions). The results generally confirmed the findings of a number of previous studies (Williams and Soutar, 2009).

First, the direct effects demonstrated that emotional value has the highest effect on experience value $(\beta=0.402)$, together with functional value $(\beta=0.4310)$, which reaffirms past research (e.g. Prebensen and Rosengren, 2016; Gallarza et al., 2015); followed by social value $(\beta=0.288)$, and novelty value $(\beta=0.250)$, howe ver, price value ( $\beta=0.133)$ had a less significant effect showing that tourists/consumers are not very sensitive to the price, this may be because international tourists visiting Shanghai bought a tourism package during the pre-trip stage and therefore, they do not perceive price as affecting his or her experience that much.

Second, the study showed that all the dimensions of experience value have an indirect effect on satisfaction, and loyalty, but they do not share the same level of statistical significance. In accordance with other studies (e.g. Yang et al., 2014; Sweeney and Soutar, 2001; Williams and Soutar, 2009; Yuan and Wu, 2008; Oliver, 1993), emotional value has the strongest significance on satisfaction and loyalty among the respondents, confirming the hedonic nature of the tourism experience. The indirect effect of social value on satisfaction, and loyalty through experience value, is in line with what was stated in other works (e.g. William and Soutar, 2000; Sánchez et al., 2006). International tourists in Shanghai like to experience services where they can feel accepted by their peers and social groups, thus filling a need for belonging. The study also revealed the importance of the novelty value in tourism services. Consumers visiting Shanghai feels the desire to experience services that lead to a certain sensation of adventure and authenticity. When tourists visit Shanghai, they are looking for what we call a "Chinese experience", contact with a different culture, a challenge in a new and perhaps exotic environment. Finally, price value had the lowest effect on satisfaction and loyalty (total effect $=0.079 ; 0.071$ ). This may be because international tourists considered public transportation and dining services to be relatively inexpensive thus providing good value for the money spent, while the most important attractions in the city are quite expensive, or as we mentioned before, because price value is more important during the traveling decision process rather than in the traveling process itself (Yang et al., 2014).

Third, the study showed that international consumers in Shanghai are more satisfied with the attractions $(t=$ 10.558), and dining $(t=10.007)$ than with the public transportation $(t=8.500)$. In addition, the study pointed out the greatest statistical significance of loyalty was in regarding to dining $(t=12.099)$, followed afterward by attractions $(t=11.589)$, and finally public transportation $(t=8.673)$. However, if we compare the level of 
satisfied tourists with loyal ones, we could assume that despite the $t$ values being statistically significant, satisfied tourists are not always one hundred percent loyal to that service, which means that international tourists, like all consumers, are more willing to recommend services to which they feel loyalty. This may be because customers risk their reputation if they feel intense loyalty (Reichheld, 2003), conversely past studies suggest that managers might assume that the level of tourist loyalty, both in their repeat behavior and in positive word of mouth, comes from a higher level of satisfaction (Gallarza et al., 2015). In contrast to other research showing that experience directly affects loyalty, this study shows that loyalty should be measured by the mediation of satisfaction. In line with previous studies, the research confirmed the strong link between experience value and satisfaction (Ryu and Jang, 2010; William and Soutar, 2010; Prebensen and Rosengren, 2016; Gallarza and Saura, 2006), as well as the direct relationship between satisfaction and loyalty (Gallarza et al., 2015; Hutchinson et al., 2009; Sánchez-Fernández et al., 2009; Wu and Liang, 2009; Ryu et al., 2008; Petrick and Backman, 2002; Choi and Chu, 2001; McDougall and Levesque, 2000).

\section{Theoretical Contributions}

Our study has the following theoretical implications.

First, the study proves the use of PLS-SEM to be a beneficial method of analysis for tourism studies. We give specific steps of how to analyze a second order hierarchical construct, as well as demonstrate that during the analysis of the reflective constructs it is not enough to measure the Fornell-Larcker criterion and cross-loadings to determine discriminant validity, rather it is also important to examine the heterotrait-monotrait ratio (HTMT) in order to achieve high specificity and sensitivity rates across all simulations.

Second, the study contributes to the literature by analyzing the experience value-satisfaction-loyalty chain of international tourists in Shanghai as there are presently few studies about it (most extant studies are in Chinese), and by expanding the body of studies which claim loyalty should be measured through satisfaction.

Third, the study promotes a better understanding of international tourists in Shanghai. For example, it demonstrates that despite tourist's complaints about shops or restaurants overcharging, especially in areas around famous attractions, and the high prices of the attractions, international tourists are not very sensitive to price. Additionally, they are more loyal to dining services and attractions than to public transportation, and therefore they are more willing to recommend these services.

\section{Practical Contributions}

Our study has the following practical implications:

First, the findings suggest that managers looking to improve customer satisfaction and loyalty, should take into consideration the emotional value when preparing the company marketing strategy, as well as in service encounters. They should facilitate positive emotions in their consumers in order to grow their numbers and make themselves more competitive in the market.

Second, when designing and developing services, firm managers should pay attention to the novelty value the firm offers. In order to attract more international tourists, they should provide a genuine and unique Chinese service experience, since many international tourists come to China looking a mystic and exotic adventure.

Third, as the study demonstrates, international consumers are very sensitive to the quality a service can provide. In order to create a pleasant experience and therefore a higher level of satisfaction and loyalty among tourists, services must be well-planned and provide a consistent level of quality.

Fourth, despite the well-known fact that Shanghai has one of the best public transportation in the world, the study shows that international tourists perceive a need for improvement in the public transportation system. We recommend employee training with at least basic English phrases in order to facilitate a better experience.

Finally, we recommend managers differentiate experience value dimensions when developing their services as well as frequently asking what their customers really want.

\section{Conclusion}

International tourists in Shanghai care more about emotions, well planned services, and inno vation than the price, which means that experience value dimensions when well managed, bridge the gap between a service provider and a consumer. Companies in Shanghai should pay special attention to the feelings and emotions of the consumers in order to attract more international tourists. Tourists who come to Shanghai are looking for new adventures, and exotic "Chinese experiences" that only service uniqueness can facilitate. As McGuire (1999) asserts, if the way tourism services are designed and delivered is unrelated to what customers value, marketing strategies will fail (p.84). Focusing on what international tourists value the most when visiting Shanghai, tourism 
services will be capable of attracting and developing more loyal consumers. Like most investigations, several limitations are present in our study. First, despite demographic aspects measured in the questionnaire, we only evaluated the frequency and percentages of every factor. For future research, control variables such as sex, age, or occupation may be analyzed in order to get better insights. Second, the research scope was limited to the city of Shanghai; other cities should be taken into consideration in future research. Third, as with previous research in this area, many of the constructs associated with satisfaction and [experience] value in a services context are intangible, elusive, and difficult to measure (William and Soutar, 2009). Hence, we suggest that in order to study and compare in greater depth the three services aforementioned, researchers could develop specific questions for any of three areas. We also recommend a study were qualitative and quantitative approaches converge in order to gain a deeper understanding.

\section{Acknowledgements}

The authors would like to thank Professor Joshua Ward for his helpful comments, time and effort in checking this article.

\section{References}

Anderson, E. W., Fornell, C., \& Lehmann, D. R. (1994) Customer Satisfaction, Market Share, and Profitability: Findings from Sweden. Journal of Marketing, 58(3), 53-66. https://doi.org/10.2307/1252310

Anderson, C. (2008). Long Tail: Why the Future of Business is Selling Less of More. Hyperion.

Athanassopoulos, A., Gounaris, S., \& Stathakopoulos, V. (2001). Behavioral responses to customer satisfaction: an empirical study. European Journal of Marketing, 5(6), 687-707. https://doi.org/10.1108/03090560110388169

Badgett, M., Moyce, M. S., \& Kleinberger, H. (2007) Turning Shoppers into Advocates. Somers, NY: IBM Institute for Business Value.

Bagozzi, R. P., \& Yi, Y. (1991). Multitrait-multimethod matrices in consumer research. Journal of Consumer Research, 17(4), 426-439. https://doi.org/10.1086/208568

Becker, J. M., Klein, K., \& Wetzels, M. (2012). Hierarchical Latent Variable Models in PLS-SEM: Guidelines for Using Reflective-Formative Type Models. Long Range Planning, 45(5-6), 359-394. https://doi.org/10.1016/j.lrp.2012.10.001

Bello, D. C., \& Etzel, M. J. (1985). The Role of Novelty in the Pleasure Travel Experience. Journal of Travel Research, 24(1), 20-26. https://doi.org/10.1177/004728758502400104

Bielen, F., \& Demoulin, N. (2007). Waiting time influence on the satisfaction-loyalty relationship in services. Managing Service Quality: An International Journal, 17(2), 174-193. https://doi.org/10.1108/09604520710735182

Bojanic, D. C. (1996). 'Consumer perceptions of price, value and satisfaction in the hotel industry: an exploratory study'. Journal of Hospitality and Leisure Marketing, 4(1), 5-22. https://doi.org/10.1300/J150v04n01_02

Boksberger, P. E., \& Melsen, L. (2011). Perceived value: a critical examination of definitions, concepts and measures for the service industry. Journal of Services Marketing, 25(3), 229-240. https://doi.org/10.1108/08876041111129209

Crompton, J. L. (1979). Motivations for pleasure vacation. Annals of tourism research, 6(4), 408-424. https://doi.org/10.1016/0160-7383(79)90004-5

Čater, B., \& Čater, T. (2009). Relationship-value-based antecedents of customer satisfaction and loyalty in manufacturing. Journal of Business \& Industrial Marketing, 24(8), 585-597. https://doi.org/10.1108/08858620910999457

Chen, C. F., \& Tsai, D. C. (2007). How destination image and evaluative factors affect behavioral intentions? Tourism Management, 28(4), 1115-1122. https://doi.org/10.1016/j.tourman.2006.07.007

Choi, T. Y., \& Chu, R. (2001). Determinants of hotel guests' satisfaction and repeat patronage in the Hong Kong hotel industry. International Journal of Hospitality Management, 20(3), 277-297. https://doi.org/10.1016/S0278-4319(01)00006-8

Eggert, A., \& Wolfgang, U. (2002), Customer Perceived Value: A Substitute for Satisfaction in Business Markets? Journal of Business \& Industrial Marketing, 17(2/3), 107-118. https://doi.org/10.1108/08858620210419754 
Edvardsson, B., Ng, G., Choo, Z. M., \& Firth, R. (2013). Why is service-dominant logic based service system better? International Journal of Quality and Service Sciences, 5(2), 171-190. https://doi.org/10.1108/JJQSS-07-2012-0007

Gallarza, M. G., \& Saura, I. G. (2006). Value dimensions, perceived value, satisfaction and loyalty: An investigation of university students' travel behavior. Tourism Management, 27(3), 437-452. https://doi.org/10.1016/j.tourman.2004.12.002

Gallarza, M. G., Arteaga, F., Del Chiappa, G., \& Gil-Saura, I. (2015). Value dimensions in consumers' experience: Combining the intra- and inter-variable approaches in the hospitality sector. International Journal of Hospitality Management, 47, 140-150. https://doi.org/10.1016/j.ijhm.2015.03.007

Grønholdt, L., Martensen, A., \& Kristensen, K. (2000). The relationship between customer satisfaction and loyalty: cross-industry differences. Total quality management, 11(4-6), 509-514. https://doi.org/10.1080/09544120050007823

Jr, J. F. H., Sarstedt, M., Hopkins, L., \& Kuppelwieser, V. G. (2014). Partial least squares structural equation modeling (PLS-SEM): An emerging tool in business research. European Business Review, 26(2), 106-121. https://doi.org/10.1108/EBR-10-2013-0128

Fornell, C. (1992). ANational Customer Satisfaction Barometer: The Swedish Experience. Journal of Marketing, 56(1), 6. https://doi.org/10.2307/1252129

Fornell, C. (1996). The American Customer Satisfaction Index: Nature, Purpose, and Findings. Journal of Marketing, 60(October), 7-18. https://doi.org/10.2307/1251898

Hair Jr, J. F., Black, W. C., Babin, B. J., Anderson, R. E., \& Tatham, R. L. (2010). SEM: An introduction. Multivariate data analysis: A global perspective, 629-686.

Hair, J. F., Hult, G. T. M., \& Ringle, C. M., Sarstedt, M. (2014). A primer on partial least squares structural equation modeling (PLS-SEM).

Hair, Jr., Joseph F., G. Tomas, M. H., Christian, M. R., \& Marko, S. (2017). A Primer on Partial Least Squares Structural Equation Modeling (PLS-SEM). SAGE Publications. Kindle Edition.

Henseler, J., Ringle, C. M., \& Sarstedt, M. (2014). A new criterion for assessing discriminant validity in variance-based structural equation modeling. Journal of the Academy of Marketing Science, 43(1), 115-135. https://doi.org/10.1007/s11747-014-0403-8

Holbrook, M. B. (1999). Introduction to consumer value. Consumer value: A framework for analysis and research, 1-28. https://doi.org/10.4324/9780203010679.ch0

Hunt, H. K. (1977), "CS/D-overview and future research directions”, in Hunt, H.K. (Ed.). Conceptualization and Measurement of Consumer Satisfaction and Dissatisfaction, Marketing Science Institute, Cambridge, MA, 455-488.

Hutchinson, J., Lai, F., \& Wang, Y. (2009). Understanding the relationships of quality, value, equity, satisfaction and behavioral intentions among golf travelers. Tourism Management, 30(2), 298-308. https://doi.org/10.1016/j.tourman.2008.07.010

Jamal, A., \& Naser, K. (2002). Customer satisfaction and retail banking: an assessment of some of the key antecedents of customer satisfaction in retail banking. International Journal of Bank Marketing, 20(4), 146-160. https://doi.org/10.1108/02652320210432936

Koenig-Lewis, N., \& Palmer, A. (2008). Experiential values over time - A comparison of measures of satisfaction and emotion. Journal of Marketing Management, 24(1-2), 69-85. https://doi.org/10.1362/026725708X273920

Lemon, K. N., \& Verhoef, P. C. (2016). Understanding Customer Experience Throughout the Customer Journey. Journal of Marketing, 80(6), 69-96. https://doi.org/10.1509/jm.15.0420

Leroi-Werelds, S., Streukens, S., Brady, M. K., \& Swinnen, G. (2014), Assessing the value of commonly used methods for measuring customer value: a multi-setting empirical study. Journal of the Academy of Marketing Science, 42(4), 430-451. https://doi.org/10.1007/s11747-013-0363-4

Luo, X. M., \& Christian, H. (2007), Neglected Outcomes of Customer Satisfaction. Journal of Marketing, 71(April), 133-149. https://doi.org/10.1509/jmkg.71.2.133

McDougall, G. H. G., \& Levesque, T. (2000). Customer Satisfaction with Services: Putting Perceived Value Into 
The Equation. Journal of Services Marketing, 14 .

https://doi.org/http://dx.doi.org/10.1108/08876040010340937

McGuire, L. (1999), Australian Services Marketing and Management, MacMillan, Melbourne.

Mittal, V., \& Kamakura, W. A. (2001). Satisfaction, repurchase intent, and repurchase behavior: investigating the moderating effect of customer characteristics. Journal of Marketing Research, 38(February), 131-142. https://doi.org/10.1509/jmkr.38.1.131.18832

Musa, R., Putit, L., Muhammad, N. Y. H. N., \& Husin, N. (2011). Investigating the impact of destination image on Total Tourists' Experience (TTE) and destination loyalty: Using structural equation modelling approach. ICBEIA 2011 - 2011 International Conference on Business, Engineering and Industrial Applications, 160-164. https://doi.org/10.1109/ICBEIA.2011.5994232

Oliver, R. L. (1993). Cognitive, affective, and attribute bases of the satisfaction response. Journal of Consumer Research, 20(3), 418-430. https://doi.org/10.1086/209358

Oliver, R. (1997). Satisfaction: Abehavioral perspective on the consumer. New York: McGraw-Hill.

Oliver, R. L. (1999). “Whence Consumer Loyalty?” Journal of Marketing, 63(Special Issue), 33-44. https://doi.org/10.2307/1252099

Petrick, J. F., \& Backman, S. J. (2002). An examination of the construct of perceived value for the prediction of golf travelers: Intentions to revisit. Journal of Travel Research, 41, 38-45.

Pine, B. J., \& Gilmore, J. H. (1999). The experience economy: work is theatre \& every business a stage. Harvard Business Press.

Parasuraman, A. (1997). Reflections on gaining competitive advantage through customer value. Journal of the Academy of Marketing Science, 25(4), 332-342. https://doi.org/10.1007/bf02894351

Prayag, G. (2008). Image, Satisfaction and Loyalty - The Case of Cape Town. Anatolia: An International Journal of Tourism and Hospitality Research, 19(2), 205-224. https://doi.org/10.1080/13032917.2008.9687069

Prebensen, N. K., \& Rosengren, S. (2016). Experience value as a function of hedonic and utilitarian dominant services. Journal of Contemporary Hospitality Management, 28(1), 113-135. https://doi.org/http://dx.doi.org/10.1108/MRR-09-2015-0216

Podsakoff, P. M., MacKenzie, S. B., Lee, J. Y., \& Podsakoff, N. P. (2003). Common method biases in behavioral research: a critical review of the literature and recommended remedies. Journal of Applied Psychology, 88(5), 879. https://doi.org/10.1037/0021-9010.88.5.879

Rahman, M. A., Qi, X., Naser, A., Saif, M., \& Ibrahim, I. B. (2017). Assessing service quality of online bill payment system using extended SERVQUAL model ( SERVQUAL-Butterfly model ): A case study of Dhaka electric supply company limited ( DESCO ), Bangladesh, (October 2016), 1-22. https://doi.org/10.1080/23311975.2017.1301195

Ryu, K., Han, H., \& Kim, T. H. (2008). The relationships among overall quick-casual restaurant image, perceived value, customer satisfaction, and behavioral intentions. International Journal of Hospitality Management, 27(3), 459-469. https://doi.org/10.1016/j.jhm.2007.11.001

Ryu, K., Han, H., \& Jang, S. (2010). Relationships among hedonic and utilitarian values, satisfaction and behavioral intentions in the fast-casual restaurant industry. International Journal of Contemporary Hospitality Management, 22(3), 416-432. https://doi.org/10.1108/09596111011035981

Reichheld, F. F. (2003). The one number you need to grow. Harvard Business Review, 81(12), 46-55. https://hbr.org/2003/12/the-one-number-you-need-to-grow

Sánchez, J., Callarisa, L., Rodríguez, R. M., \& Moliner, M. A. (2006). Perceived value of the purchase of a tourism product. Tourism Management, 27(3), 394-409. https://doi.org/10.1016/j.tourman.2004.11.007

Sánchez-Fernández, R., \& Iniesta-Bonillo, M. A. (2007). The concept of perceived value: a systematic review of the research. Marketing Theory, 7(4), 427-451. https://doi.org/10.1177/1470593107083165

Sarstedt, M., Ringle, C. M., Smith, D., Reams, R., \& Hair, J. F. (2014). Partial least squares structural equation modeling (PLS-SEM): A useful tool for family business researchers. Journal of Family Business Strategy, 5(1), 105-115. https://doi.org/10.1016/j.jfbs.2014.01.002

Sheth, J. N., Newman, B. I., \& Gross, B. L. (1991), Consumption Values and Market Choices. Theory and 
Applications, Cincinnati, OH: South-Western Publishing Co.

Silvestro, R., \&Cross, S. (2000). Applying the service profit chain in a retail environment. International Journal of Service Industry Management, 11 (3), 244-268. https://doi.org/10.1108/09564230010340760

Stigler, S. M. (1989). Francis Galton's account of the invention of correlation. Statistical Science, 73-79. https://doi.org/10.1214/ss/1177012580

Sweeney J. C., Soutar G. N., \& Johnson L. W. (1996) Retail service quality and perceived value: A comparison of two models. Journal of Retailing and Consumer Services, 4(1), 39-48. https://doi.org/10.1016/S0969-6989(96)00017-3

Sweeney, J. C., \& Soutar, G. N. (2001). Consumer perceived value: The de velopment of a multiple item scale. Journal of Retailing, 77(2), 203-220. https://doi.org/10.1016/S0022-4359(01)00041-0

Uriely, N. (2005). The tourist experience: conceptual developments. Annals of Tourism Research, 32(1), 199-216. https://doi.org/10.1016/j.annals.2004.07.008

Westbrook, A. (1980). Interpersonal affective influences on consumer satisfaction with with products. Journal of Consumer Research, 7, 49-54. https://doi.org/10.1086/208792

Westbrook, R. A., Ernest, R. C., \& Roger, L. J. (1983). Modelling Consumer Satisfaction Processes Using Experience-Based Norms. Journal of Marketing Research, 20(August), 296-304.

Westbrook, R. A., \& Richard, L. O. (1991). The Dimensionality of Consumption Emotion Patterns and Consumer Satisfaction. Journal of Consumer Research, 18(1), 84-91. https://doi.org/10.1086/209243

Williams, P., \& Soutar, G. N. (2009). Value, Satisfaction and Behavioral Intentions in an Adventure Tourism Context. Annals of Tourism Research, 36(3), 413-438. https://doi.org/10.1016/j.annals.2009.02.002

Wu, C. H. J., \& Liang, R. D. (2009). Effect of experiential value on customer satisfaction with service encounters in luxury-hotel restaurants. International Journal of Hospitality Management, 28, 586-593. https://doi.org/10.1016/j.ijhm.2009.03.008

Yang, Y., Liu, X., Jing, F., \& Li, J. (2014). How Does Perceived Value Affect Travelers' Satisfaction and Loyalty? Social Behavior and Personality, 42(10), 1733-1744. https://doi.org/10.2224/sbp.2014.42.10.1733

\section{Appendix 1}

\begin{tabular}{lcccccc}
\hline \multicolumn{5}{c}{ Total Variance Explained } \\
\hline & \multicolumn{5}{c}{ Initial Eigenvalues } & Extraction Sums of Squared Loadings \\
\cline { 2 - 6 } Component & Total & Variance & Cumulative $\%$ & Total & Variance & Cumulative $\%$ \\
\hline 1 & 7.266 & 36.328 & 36.328 & 7.266 & 36.328 & 36.328 \\
2 & 2.507 & 12.537 & 48.864 & & \\
3 & 1.522 & 7.611 & 56.476 & & \\
4 & 1.410 & 7.051 & 63.526 & & \\
5 & 1.199 & 5.993 & 69.519 & & \\
6 & 1.070 & 5.351 & 74.870 & & \\
7 & 0.823 & 4.117 & 78.987 & & \\
8 & 0.656 & 3.278 & 82.266 & & \\
9 & 0.536 & 2.678 & 84.943 & & \\
10 & 0.454 & 2.272 & 87.215 & & \\
11 & 0.376 & 1.879 & 89.094 & & \\
12 & 0.346 & 1.731 & 90.825 & & \\
13 & 0.316 & 1.580 & 92.405 & & \\
14 & 0.291 & 1.456 & 93.861 & & \\
15 & 0.272 & 1.361 & 95.222 & & \\
16 & 0.237 & 1.184 & 96.406 & & \\
17 & 0.208 & 1.040 & 97.446 & & \\
18 & 0.186 & 0.930 & 98.376 & & \\
19 & 0.177 & 0.887 & 99.263 & & \\
20 & 0.147 & 0.737 & 100.000 & & \\
\hline
\end{tabular}

\section{Copyrights}

Copyright for this article is retained by the author(s), with first publication rights granted to the journal.

This is an open-access article distributed under the terms and conditions of the Creative Commons Attribution license (http://creativecommons.org/licenses/by/4.0/). 